Penelitian

\title{
Escherichia coli 0157:H7 Resistan Antibiotik pada Daging Kebab yang Dijual di Sekitar Kampus IPB Dramaga Bogor
}

\author{
(Escherichia coli O157:H7 Resistant Antibiotic on Kebab Meat \\ Sold Around IPB University Dramaga Bogor) \\ Devi Yanti Sari ${ }^{*}$, Herwin Pisestyani ${ }^{2}$, Denny Widaya Lukman² \\ ${ }^{1}$ Mahasiswa Program Studi Kesehatan Masyarakat Veteriner Sekolah Pascasarjana IPB \\ ${ }^{2}$ Departemen Ilmu Penyakit Hewan dan Kesehatan Masyarakat Veteriner, Fakultas Kedokteran Hewan, \\ Institut Pertanian Bogor, Jl. Agatis Kampus IPB Dramaga Bogor, 16680 \\ *Penulis untuk korespondensi: devi.y.sari@gmail.com \\ Diterima 16 Juni 2021, Disetujui 3 September 2021
}

\begin{abstract}
ABSTRAK
Kebab merupakan salah satu makanan siap saji atau ready to eat (RTE) yang populer di seluruh dunia. Escherichia coli (E. coli) O157:H7 banyak dihubungkan dengan kejadian outbreak foodborne disease pada kebab. Kontaminasi E. coli O157:H7 resistan antibiotik pada kebab dapat menimbulkan masalah kesehatan serius. Penelitian ini bertujuan mengidentifikasi E. coli O157:H7 resistan antibiotik yang diisolasi dari daging kebab yang dijual di sekitar Kampus IPB Dramaga Bogor. Total 43 sampel daging kebab diambil dari seluruh pedagang kebab di sekitar Kampus IPB Dramaga dalam radius $2 \mathrm{~km}$ dari batas terluar Kampus. Isolasi dan identifikasi E. coli mengacu pada Standar Nasional Indonesia (SNI) 2897:2008 dari Badan Standardisasi Nasional tentang Metode Pengujian Cemaran Mikroba dalam Daging, Telur, dan Susu, serta Hasil Olahannya. Uji serotyping E. coli O157:H7 menggunakan uji Serologis. Uji resistansi E. coli O157:H7 mengacu pada standar Clinical Laboratory Standards Institute (CLSI) dan dilakukan terhadap 10 jenis antibiotik menggunakan metode Kirby-Bauer disk diffusion. Data yang diperoleh dianalisis secara deskriptif. Hasil penelitian menunjukkan enam isolat positif E. coli $\mathrm{O} 157: \mathrm{H} 7$ (31.6\%; 6/19) yang resistan terhadap ampisilin, amoksisilin-asam klavulanat, gentamisin, siprofloksasin, enrofloksasin, dan kolistin sulfat dengan satu isolat termasuk multidrug resistant (MDR). Semua isolat E. coli O157:H7 masih sensitif terhadap trimethoprim-sulfametoksasol, oksitetrasiklin, dan kloramfenikol.
\end{abstract}

Kata kunci : E. coli O157:H7, resistansi antibiotik, multidrug resistant, daging kebab

\begin{abstract}
Kebab is one of ready to eat (RTE) which has become popular around the world. Escherichia coli (E. coli) O157:H7 has related to foodborne disease outbreak in kebab. The E. coli O157:H7 resistant antibiotic contamination in kebab can cause serious problems in human health. This study was aimed to identified the occurrence of $\mathrm{E}$. coli O157:H7 resistant antibiotic isolated from kebab meat sold around IPB University Dramaga Bogor. A total of 43 kebab meat sample were taken from all kebab vendors in the radius $2 \mathrm{~km}$ around the outside border of IPB University. Isolation and identification of E. coli were referred to the Guideline for Laboratory Analysis on Examination of Microbial Contamination in Meat, Egg, and Milk in SNI 2897:2008 issued by the National Standardization Agency of Indonesia. Isolation and identification E. coli $\mathrm{O} 157: \mathrm{H} 7$ carried out using Serologic test. The E. coli O157:H7 resistance test against ten antibiotics based on Clinical Laboratory Standards Institute (CLSI) using Kirby-Bauer disk diffusion methods. The result data was analized descriptively. The results showed six isolates were positive E. coli O157:H7 (31.6\%; 6/19) and resistant to ampicillin, amoxicillin-clavulanate, gentamicin, ciprofloxacin, enrofloxacin, and colistin sulphate. One isolate was also a multidrug resistant (MDR). All of the $\mathrm{E}$. coli $\mathrm{O} 157: \mathrm{H} 7$ isolates were still susceptible to trimethoprim-sulfamethoxazole, oxytetracycline, and chloramphenicol.
\end{abstract}

Key words: E. coli O157:H7,antibiotic resistance, multidrug resistant, kebab meat 


\section{PENDAHULUAN}

Kebab merupakan salah satu makanan siap saji atau ready to eat (RTE) yang populer di seluruh dunia termasuk di Indonesia. Kebab berasal dari Timur Tengah dan salah satu jenis kebab yang banyak dijual di Indonesia adalah Doner Kebab. Kebab merupakan salah satu RTE yang menjadi favorit di kalangan mahasiswa. Doner kebab banyak dikaitkan dengan masalah keamanan pangan di beberapa negara. Salah satu jenis bakteri yang banyak dihubungkan dengan kejadian foodborne disease pada kebab adalah Escherichia coli (E. coli) terutama strain E. coli O157:H7. The EU Rapid Alert System for Food and Feed (RASFF) mencatat 97 notifikasi kasus terkait kebab pada periode tahun 2000 sampai 2017 (Bonilauri et al. 2018). Setiap tahun diperkirakan terjadi 265000 kasus infeksi shiga toxin-producing E. coli (STEC) pada manusia di Amerika Serikat dan 36\% diantaranya disebabkan oleh STEC O157 (CDC, 2014).

Sebagian besar strain E. coli tidak berbahaya dan menjadi mikroflora normal di usus manusia dan hewan, tetapi terdapat strain E. coli yang bersifat patogen. Selain di usus manusia dan hewan E. coli juga dapat ditemukan di lingkungan, makanan dan minuman (CDC, 2014). Escherichia coli O157:H7 merupakan salah satu strain E. coli patogen dari pathotype enterohemorrhagic E. coli (EHEC) atau shiga toxin-producing $E$. coli (STEC) yang termasuk zoonosis. Shiga toxin-producing E. coli (STEC) dihubungkan dengan beberapa kasus outbreak diare, hemorrhagic colitis (HC), hemolytic uremic syndrome (HUS) pada manusia. Infeksi STEC di manusia bervariasi mulai dari tanpa gejala klinis hingga kematian. Transmisi $E$. coli $0157: \mathrm{H} 7$ ke manusia melalui rute feco-oral dengan mengonsumsi makanan atau minuman yang terkontaminasi, seperti daging cincang, susu tanpa pasteurisasi, sayuran dan buah-buahan yang terkontaminasi melalui air, keju, jus buah, kecambah, lettuce (Kiranmayi et al., 2010). Dosis infeksi E. coli O157:H7 sangat sedikit yaitu < 100 colony forming unit per gram (CFU/g) (Beneduce et al. 2003; Constable et al., 2017; Rivas et al., 2019).

Infeksi E. coli O157:H7 dapat terjadi pada orang dewasa, anak-anak, dan lanjut usia. Gejala klinis infeksi STEC diawali dengan muntah, demam ringan, sakit perut dan diare tanpa darah pada 1-2 hari pertama, diikuti dengan diare berdarah dan hemorrhagic colitis (Rivas et al., 2019). Kejadian HUS biasanya bersifat akut yang diawali diare dengan atau tanpa darah kemudian dapat berlanjut dengan kejadian anemia hemolitik, trombositopenia, dan gagal ginjal.
Infeksi yang berkembang menjadi HUS biasanya terjadi pada anak-anak di bawah umur 5 tahun. Mortality rate tinggi pada anak-anak dan lanjut usia (Percival \& Williams, 2014). Pada orang dewasa colitis akibat E. coli O157:H7 juga dapat menyebabkan HUS dan thrombotic thrombocytopenic purpura (Ameer et al., 2020).

Konsumsi pangan asal hewan yang mengandung bakteri patogen seperti E. coli O157:H7 yang resistan terhadap antibiotik dapat menyebabkan masalah serius terhadap kesehatan masyarakat. Antimicrobial resistance (AMR) atau resistansi antibiotik telah menjadi masalah kesehatan global di seluruh dunia. Menurut O'Neill (2014) pada tahun 2050 AMR diperkirakan akan menyebabkan kematian 10 juta jiwa penduduk di dunia setiap tahun. Informasi mengenai keberadaan E. coli O157:H7 yang resistan antibiotik pada kebab masih sangat sedikit di Indonesia sehingga penelitian ini dilakukan dengan tujuan mengidentifikasi keberadaan E. coli O157:H7 dan sifat resistansinya terhadap antibiotik pada kebab.

\section{BAHAN DAN METODE}

\section{Waktu dan Tempat Penelitian}

Penelitian dilakukan pada bulan Agustus sampai Desember 2019. Sampel daging kebab diperoleh dari 9 pedagang kebab yang berjualan di sekitar Kampus IPB Dramaga Bogor dalam radius $2 \mathrm{~km}$ dari batas luar Kampus. Pengujian sampel dilakukan di Laboratorium Kesehatan Masyarakat Veteriner Divisi Kesmavet dan Epidemiologi Fakultas Kedokteran Hewan Institut Pertanian Bogor untuk uji isolasi dan identifikasi $E$. coli dan uji resistansi terhadap antibiotik. Pengujian identifikasi strain E. coli O157:H7 dilakukan di Balai Besar Penelitian Veteriner (BBalitvet).

\section{Pengambilan Sampel}

Pengambilan sampel dilakukan terhadap seluruh pedagang kebab dalam radius $2 \mathrm{~km}$ dari batas terluar Kampus IPB Dramaga karena radius tersebut mayoritas mahasiswa tinggal dan mayoritas pedagang kebab berjualan di sekitar kampus. Berdasarkan survey pendahuluan didapatkan 9 pedagang dalam radius $2 \mathrm{~km}$ dari batas terluar Kampus IPB Dramga. Sampel daging kebab diambil dari masingmasing pedagang sebanyak 5 kali pada hari yang berbeda. Total sampel yang dapat diambil 43 sampel. Pengambilan sampel dilakukan pada pukul 19.00-21.00 WIB. Pengambilan sampel dilakukan 
secara aseptis, kemudian ditempatkan pada plastik steril dan diberi identitas sampel (label) lalu disimpan dalam cool box dengan suhu 4-10 ${ }^{\circ} \mathrm{C}$. Sampel dibawa ke Laboratorium Kesehatan Masyarakat Veteriner, Fakultas Kedokteran Hewan, Institut Pertanian Bogor untuk diisolasi dan identifikasi E. coli dan uji resistansi terhadap antibiotik. Isolat E. coli terkonfirmasi dengan uji IMViC kemudian dibawa ke BBalitvet untuk identifikasi strain E. coli O157:H7.

\section{Isolasi dan Identifikasi Escherichia coli}

Uji isolasi dan identifikasi E. coli pada penelitian ini mengacu pada SNI 2897:2008 dari Badan Standardisasi Nasional tentang Metode Pengujian Cemaran Mikroba dalam Daging, Telur, dan Susu, serta Hasil Olahannya. Escherichia coli (ATCC) 25922 digunakan sebagai kontrol positif dalam setiap pengujian E.coli. Metode isolasi dan identifikasi E. coli menggunakan metode Most Probable Number (MPN) seri 3 tabung. Sebanyak 25 gram sampel daging kebab ditambahkan kedalam larutan buffered peptone water (BPW) 0.1\% (Oxoid CM1049, England) dan dihomogenkan.

Sebanyak $1 \mathrm{ml}$ suspensi dipindahkan ke lauryl tryptose broth/lauryl sulphate broth (LTB) (Oxoid CM0451, England) dan hasil positif pada LTB dipindahkan ke EC (Escherichia coli) broth (Oxoid CM0853, England) lalu hasil positif diinokulasi ke media selektif L-EMB. Koloni yang diduga E. coli akan berwarna hitam/gelap pada bagian pusat koIoni dan berwarna hijau metalik. Koloni yang diduga E. coli pada media eosin methylene blue agar (Levine) (L-EMB) (Oxoid CMoo69, England) lalu diinokulasikan pada nutrient agar (NA) (Oxoid CMooo3, England), untuk pengujian lebih lanjut. Isolat pada NA kemudian diuji dengan uji biokimia indole, methyl red, Voges Proskauer, dan citrate (IMViC) untuk konfirmasi. Isolat $E$. coli merupakan isolat dengan hasil uji IMViC ++--.

\section{Isolasi dan Identifikasi E. coli O157:H7}

Isolat dengan hasil uji IMViC yang menunjukan positif E. coli kemudian dibawa ke BBalitvet untuk dilakukan serotyping E. coli O157:H7. Menurut Suardana et al., (2014) dan Rinca et al., (2016) isolasi dan identifikasi E. coli O157:H7 diawali dengan membiakkan E. coli pada media sorbitol McConkey agar (SMAC) dan diinkubasikan $37{ }^{\circ} \mathrm{C}$ selama 24 jam. KoIoni E. coli O157 tidak dapat memfermentasi sorbitol dan menunjukkan hasil koloni tidak berwarna (colourless). Uji konfirmasi E. coli O157 dilakukan dengan uji aglutinasi latex (latex agglutination). Menurut Rachmawati \& Ariyanti (2017) hasil positif 0157 ditandai dengan terbentuknya aglutinasi seperti endapan pasir dalam waktu 1-3 menit.

Penentuan isolat E. coli O157 sebagai E. coli O157:H7 dapat dilakukan dengan uji serologis menggunakan antiserum $\mathrm{H} 7$. Koloni yang positif pada uji latex agglutination O157 ditumbuhkan 2 kali pasase pada media sulfide indol motility (SIM). Hasil positif ditandai dengan terbentuknya warna putih berkabut di sekitar tempat tusukan pada media SIM.

Biakan positif kemudian ditanam pada media brain heart infusion (BHI) dan diinkubasikan pada suhu $37{ }^{\circ} \mathrm{C}$ selama 24 jam. Isolat pada BHI selanjutnya diinaktivasi dengan formalin $40 \%$ dengan perbandingan $0,3 \mathrm{ml}$ formalin dan $100 \mathrm{ml} \mathrm{BHI}$, yang kemudian disebut sebagai antigen. Antigen lalu diuji dengan antiserum $\mathrm{H} 7$ yang diencerkan dengan perbandingan 1:500. Sebanyak 50 $\mu$ lantigen dan 50 $\mu \mathrm{l}$ antiserum $\mathrm{H} 7$ dimasukkan ke dalam microplate dan diletakkan pada penangas air pada suhu $50{ }^{\circ} \mathrm{C}$ selama 1 jam. Hasil positif ditandai dengan terbentuknya endapan seperti butiran pasirpada dasar microplate (Suardana et al., 2008; Suardana et al., 2014; Rinca et al., 2016).

\section{Pengujian Resistensi Antibiotik}

Uji resistansi terhadap antibiotik dilakukan pada semua isolat $\mathrm{E}$. coli O157:H7 yang didapat dari sampel daging kebab dan mengacu pada Clinical Laboratory Standard Institute (CLSI) menggunakan metode Kirby-Bauer disk diffusion. Uji resistansi antibiotik dilakukan terhadap sepuluh jenis antibiotik, yaitu ampisilin (AMP) $10 \mu \mathrm{g}$ (Oxoid CToo03B, England), amoksisilin-asam klavulanat (AMC) $30 \mu \mathrm{g}$ (Oxoid CT0223B, England), sefotaksim(CTX) $30 \mu \mathrm{g}$ (Oxoid CT0166B, England), gentamisin (CN) $10 \mu \mathrm{g}$ (Oxoid CTo024B, England), trimetoprim-sulfametoksasol (SXT) $25 \mu \mathrm{g}$ (Oxoid CT0052B, England), siprofloksasin (CIP) $5 \mu \mathrm{g}$ (Oxoid CT0425B, England), enrofloksasin (ENR) $5 \mu \mathrm{g}$ (Oxoid CT0639B, England), oksitetrasiklin (OT) $30 \mu \mathrm{g}$ (Oxoid CTo041B, England), kloramfenikol (CL) $30 \mu \mathrm{g}$ (Oxoid CTo013B, England), dan kolistin sulfat (CT) $30 \mu \mathrm{g}$ (Oxoid CT0017B, England).

Cakram tanpa kandungan bahan antibiotik (cakram kosong) digunakan dalam setiap uji sebagai kontrol negatif. Bakteri E. coli disiapkan dalam bentuk suspensi dengan kekeruhan yang setara dengan 0.5 McFarland $\left(1-2 \times 10^{8} \mathrm{CFU} / \mathrm{mL}\right)$. Biakan tersebut kemudian diambil dengan cotton swab steril dan disebarkan pada permukaan Mueller Hinton agar (MHA) (Oxoid CM0337, England), lalu didiamkan 
selama 5 menit, selanjutnya kertas cakram komersial yang berisi antibiotik diletakkan di atas MHA, yang telah disebar dengan biakan murni dengan jarak 25$30 \mathrm{~mm}$. Biakan tersebut kemudian diinkubasi pada suhu $35{ }^{\circ} \mathrm{C}$ selama $18-24$ jam. Penentuan kategori sensitif, intermediet, dan resistan ditentukan melalui ukuran zona hambat yang terbentuk berdasarkan standar CLSI (2018) dan CLSI (2014) untuk antibiotik kolistin.

\section{Analisis Data}

Data hasil pengujian di laboratorium dianalisis secara deskriptif dan disajikan dalam bentuk tabel.

\section{HASIL}

Hasil penelitian menunjukkan dari 43 sampel daging kebab diperoleh 9 sampel positif E. coli dan dalam 5 sampel positif E. coli terdapat E. coli O157:H7. Sebanyak 19 isolat E. coli didapatkan berdasarkan uji IMViC dengan 6 isolat diantaranya termasuk strain E. coli $\mathrm{O} 157: \mathrm{H} 7$ (6/19; 31.6\%) berdasarkan uji Serologis.

Hasil uji resistansi E. coli O157:H7 menunjukkan 3 isolat $\mathrm{E}$. coli $\mathrm{O} 157: \mathrm{H} 7(3 / 6 ; 50 \%)$ resistan terhadap gentamisin. Selanjutnya 2 isolat resistan terhadap siprofloksasin dan kolistin sulfat. Isolat yang resistan terhadap ampisilin, amoksisilin, dan enrofloksasin masing-masing hanya 1 isolat. Satu isolat E. coli O157:H7 resistan terhadap 4 jenis antibiotic ampisilin enrofloksasin, siprofloksasin dan gentamisin (AMP-ENR-CIP-CN). Semua isolat masih sensitif terhadap, trimethoprim sulfametoksasol, oksitetrasiklin, dan kloramfenikol. Sebanyak 3 isolat termasuk kategori intermediet terhadap sefotaksim (Tabel 1).

\section{PEMBAHASAN}

\section{Keberadaan E. coli O157:H7 pada kebab}

Hasil uji identifikasi E. coli pada daging kebab menunjukkan keberadaan E. coli yang cukup tinggiSembilan sampel positif E. coli ditemukan dari total 43 sampel daging kebab yang diambil (20.9\%). Berdasarkan uji konfirmasi IMViC didapatkan 19 isolat $E$. coli dan 6 isolat merupakan strain $E$. coli O157: $\mathrm{H} 7(31.6 \% ; 6 / 19)$. Tingginya persentase daging kebab yang terkontaminasi E. coli pada penelitian ini cukup mengkhawatirkan mengingat terdapat strain E. coli $\mathrm{O} 157: \mathrm{H} 7$ yang berisiko menyebabkan foodborne disease bagi konsumen. Persentase E. coli O157:H7 pada penelitian ini lebih tinggi dari penelitian yang dilakukan oleh Ulukanli et al., (2006) yang menemukan $11.25 \%$ isolat E. coli O157: $\mathrm{H} 7$ pada kebab di Kars, Turki. Berbeda dengan penelitian Osaili et al. (2014) yang tidak menemukan E. coli O157:H7 pada sampel kebab di Yordania.

Kualitas mikrobiologik pada Doner kebab dapat dipengaruhi oleh berbagai faktor, seperti kualitas bahan mentah, efektivitas proses pemasakan, sanitasi tempat penjualan, dan higiene personal.

Tabel 1 Resistansi E. coli O157:H7 pada daging kebab yang dijual di sekitar Kampus IPB Dramaga

\begin{tabular}{|c|c|c|c|c|c|c|c|c|c|c|c|c|c|}
\hline \multirow[t]{2}{*}{ Kode Sampel } & \multicolumn{10}{|c|}{ Jenis Antibiotik } & \multicolumn{3}{|c|}{ Total } \\
\hline & AMP & $\mathrm{AMC}$ & ENR & CIP & SXT & OT & $\mathrm{CN}$ & CTX & $\mathrm{CL}$ & CT & $\mathrm{R}$ & 1 & $S$ \\
\hline $3 / 5 / T_{2} / 10^{-1}$ & $S$ & $\mathrm{R}$ & $\mathrm{S}$ & $\mathrm{S}$ & $S$ & $S$ & $\mathrm{~S}$ & $\mathrm{~S}$ & $\mathrm{~S}$ & $\mathrm{R}$ & 2 & 0 & 8 \\
\hline $1 / 2 / T_{3} / 10^{-1}$ & $S$ & $\mathrm{~S}$ & $\mathrm{~S}$ & $S$ & $S$ & $S$ & $\mathrm{R}$ & I & $S$ & $S$ & 1 & 1 & 7 \\
\hline $2 / 4 / \mathrm{T} 1 / 10^{-2}$ & $\mathrm{R}$ & $\mathrm{S}$ & $\mathrm{R}$ & $\mathrm{R}$ & $S$ & $S$ & $\mathrm{R}$ & I & $S$ & $S$ & 4 & 1 & 5 \\
\hline $3 / 3 / T_{3} / 10^{-1}$ & $S$ & $S$ & $\mathrm{~S}$ & $\mathrm{R}$ & $S$ & $S$ & $S$ & I & $S$ & $S$ & 1 & 1 & 8 \\
\hline $1 / 2 / \mathrm{T} 1 / 10^{-1}$ & $S$ & $S$ & $S$ & $S$ & $S$ & $S$ & $S$ & $S$ & $S$ & $S$ & 0 & 0 & 10 \\
\hline $3 / 6 / T_{3} / 10^{-2}$ & $\mathrm{~S}$ & $\mathrm{~S}$ & $\mathrm{~S}$ & $\mathrm{~S}$ & $\mathrm{~S}$ & $S$ & $\mathrm{R}$ & $\mathrm{S}$ & $\mathrm{S}$ & $\mathrm{R}$ & 2 & 0 & 8 \\
\hline
\end{tabular}

Keterangan: $\mathrm{AMP}=$ ampisilin; $\mathrm{AMC}=$ amoksisilin-asam klavulanat, $\mathrm{ENR}=$ enrofloksasin;

$\mathrm{CIP}=$ siprofloksasin; $\mathrm{SXT}=$ trimetoprim-sulfametoksasol; OT= oksitetrasiklin;

$\mathrm{CN}=$ gentamisin; $\mathrm{CTX}=$ sefotaksim; $\mathrm{CL}=$ kloramfenikol; $\mathrm{CT}=$ kolistin sulfat;

$\mathrm{R}=$ resistan, $\mathrm{I}=$ intermediet, $\mathrm{S}=$ sensitif 
Masalah keamanan pangan dapat muncul tergantung kualitas daging mentah, dan atau pengolahan (Cagri-Mehmetoglu, 2018).

Kontaminasi E. coli $\mathrm{O} 157: \mathrm{H} 7$ dapat berasal dari kontaminasi feses mulai dari peternakan, rumah potong hewan (RPH) hingga penyajian. Kontaminasi di peternakan dapat terjadi karena sapi merupakan reservoir E. coli O157:H7. Menurut Constable et al. (2017) E. coli O157:H7 dapat hidup sementara pada saluran pencernaan ruminansia sehat. Shedding E. coli $\mathrm{O} 157: \mathrm{H} 7$ melalui feses dapat terjadi 1 sampai 3 bulan bahkan sampai 2 tahun. Identifikasi strain E. coli O157:H7 pada sapi di Indonesia pernah dilakukan oleh Darmawan et al. (2015) yang menemukan 3.4\% E. coli $0157: \mathrm{H} 7$ dari 58 sampel feses sapi Bali. Beberapa studi juga pernah menemukan adanya E. coli O157:H7 pada hewan dan pisau di RPH (Bekele et al., 2014) serta pada daging di RPH (Abreham et al., 2019). Escherichia coli O157:H7 juga pernah ditemukan pada pangan asal hewan di restoran Kota Bishoftu, Ethiopia (Bedasa et al. 2018). Menurut Abreham et al. (2019) untuk menurunkan kontaminasi feses yang mengandung E. coli O157:H7 pada daging, pakan dan air dapat dilakukan dengan mengurangi jumlah E. coli O157:H7 pada hewan.

Kontaminasi E. coli O157:H7 saat penyajian dapat disebabkan oleh kurangnya praktik higiene dan sanitasi. Menurut Kwiri et al. (2014) penanganan yang buruk saat penjualan dapat berkontribusi dalam prevalensi E. coli pada RTE. Escherichia coli merupakan bakteri indikator adanya pencemaran fecal (Wibawa, 2008). Keberadaan E. coli O157:H7 pada feses manusia pernah dilaporkan pada pasien diare di Indonesia (Bakri et al., 2010). Kurangnya praktik higiene dan sanitasi serta kurangnya fasilitas sarana air bersih maupun sarana cuci tangan juga ditemukan saat penelitian. Selain itu ditemukan penggunaan sarung tangan yang sama dan jarang diganti, penggunaan jam tangan atau perhiasan saat penyiapan kebab. Beberapa pedagang juga menggunakan telpon seluler saat proses penyiapan kebab.

Risiko kontaminasi dari peralatan seperti penggunaan pisau yang sama untuk memotong sayuran dan daging kebab juga ditemukan saat pengamatan. Hal ini dapat menyebabkan terjadinya kontaminasi silang. Lokasi kios kebab dalam penelitian ini juga rata-rata di pinggir jalan, hal ini berisiko menyebabkan terjadinya kontaminasi mikroorganisme pada kebab. Menurut Wibawa (2008) kontaminasi silang dapat berasal dari penggunaan wadah atau alat pengolahan dan penyimpanan secara bersama-sama sehingga dapat menyebabkan keracunan makanan. Lokasi tempat pegolahan makanan merupakan salah satu faktor penentu kualitas higiene dan sanitasi makanan. Lokasi tempat pengolahan makanan harus jauh dari sumber pencemaran yang diakibatkan kondisi lingkungan yang tidak baik seperti debu, udara kotor dan banjir.

Penyimpanan kembali daging kebab yang tidak habis juga masih dilakukan oleh pedagang kebab pada penelitian ini. Menurut Cagri-Mehmetoglu (2018) jika sisa daging kebab yang tidak habis dipanaskan kembali untuk dijual esok hari, dapat membahayakan kesehatan. Mikroorganisme patogen yang terdapat pada daging kebab tidak mati jika suhu pemasakan daging kebab kurang matang. Rute infeksi E. coli O157:H7 yang paling banyak disebabkan karena suhu pemasakan yang kurang matang (Chapman et al., 2001; Ulukanli \& Cavli, 2006). Strain STEC dapat mati dengan suhu pemasakan internal daging minimal $70{ }^{\circ} \mathrm{C}$ (WHO, 2018). Mikroorganisme patogen tidak dapat mati pada bagian daging yang tidak mendapat panas yang cukup (CagriMehmetoglu, 2018). Berdasarkan pengukuran suhu daging kebab saat pengambilan sampel, terdapat suhu pemasakan daging kebab yang kurang dari 70 ${ }^{\circ} \mathrm{C}$ sehingga $\mathrm{E}$. coli $\mathrm{O} 157: \mathrm{H} 7$ masih dapat ditemukan pada daging kebab.

Kontaminasi E. coli $\mathrm{O} 157: \mathrm{H} 7$ pada daging kebab dapat menyebabkan masalah kesehatan yang serius bagi konsumen. Menurut Rivas et al. (2019) hanya dengan dosis rendah yaitu $<100$ colony forming unit per gram (CFU/g) E. coli O157:H7 sudah dapat menginfeksi manusia dan menyebabkan HC dan HUS.

\section{E. coli O157:H7 Resistan Antibiotik dan MDR}

Penggunaan antibiotik pada pengobatan infeksi E. coli $\mathrm{O} 157: \mathrm{H} 7$ di manusia masih menjadi perdebatan. Penggunaan antibiotik dalam pengobatan infeksi E. coli O157:H7 disinyalir dapat meningkatkan risiko kejadian HUS sehingga pengobatan yang dilakukan bersifat suportif dan mempertahankan status hidrasi (CDC, 2014; Ameer et al., 2019). Namun menurut Schroeder et al., (2002) perjalanan penyakit dapat dicegah dengan penggunaan antibiotik pada tahap awal. Uji resistansi antibiotik diperlukan untuk respon lebih baik (Quinn et al., 2011).

Penelitian ini menemukan resistansi E. coli O157:H7 terhadap tujuh jenis antibiotik (ampisilin, amoksisilin-asam klavulant, sefotaksim, gentamisin, siprofloksasin, enrofloksasin, kolistin sulfat). Sementara tiga jenis antibiotik lainnya masih sensitif 
(trimethoprim-sulfametoksasol, oksitetrasiklin, dan kloramfenikol). Menurut Constable et al. (2017) resistansi E. coli O157:H7 banyak terjadi terhadap antibiotik tetrasiklin, sulfametoksasol, sefalotin dan ampisilin. Sementara Amezquita-Lopez et al., (2016) menemukan strain STEC O157 dan non O157 pada hewan ternak di Culiacan Valley, Mexico yang resistan terhadap golongan aminoglikosida, tetrasiklin, sefalosporin dan penisilin, tetapi masih sensitif terhadap florokuinolon, kuinolon, dan sulfonamid. Penggunaan antbiotik yang tidak bijak di peternakan dan dunia medis dapat berperan dalam penyebaran resistansi antibiotik. Penggunaan antibiotik yang berlebihan dalam produksi pangan asal hewan untuk pemacu pertumbuhan, pencegahan atau pengobatan penyakit hewan telah berkontribusi dalam penyebaran resistansi antimikrob (Malathi et al., 2014; Economou \& Gousia, 2015).

Kejadian resistansi E. coli $\mathrm{O} 157: \mathrm{H} 7$ terhadap antibiotik juga telah ditemukan di manusia. Sebuah studi yang pernah dilakukan di Michigan USA menemukan STEC O157 dan non O157 dari pasien manusia selama tahun 2010-2014. Resistansi yang ditemukan paling banyak terjadi terhadap ampisilin, trimetoprim-sulfametoksasol dan siprofloksasin (Mukherjee et al., 2017).

Berdasarkan hasil penelitian ini resistansi E. coli O157:H7 tertinggi terjadi pada gentamisin. Gentamisin merupakan antibiotik golongan aminoglikosida berspektrum luas yang digunakan pada manusia dan hewan. Gentamisin termasuk salah satu antibiotik yang banyak digunakan pada sapi diantaranya untuk pengobatan enteritis (Economou \& Gousia, 2015).

Hasil yang perlu diwaspadai terlihat dari terjadinya resistansi E. coli O157:H7 terhadap kolistin dan sefotaksim yang ditunjukkan pada penelitian ini. Kolistin merupakan antibiotik yang digunakan sebagai pilihan terakhir dalam pengobatan Multi-drug Resistant (MDR) bakteri Gram negatif (Liu \& Liu 2018). Uji resistansi terhadap sefotaksim dalam penelitian ini menunjukkan hasil intermediet. Antibiotik sefotaksim digunakan secara umum diantaranya dalam pengobatan pasien infeksi saluran kemih, infeksi saluran pernafasan, meningitis, neonatal sepsis, osteomyelitis, typhoid fever (Greenwood, 2010).

Penelitian ini juga menemukan satu isolat MDR E. coli O157:H7. Multi-Drug Resistant (MDR) didefinisikan sebagai resistansi terhadap sekurangnya satu jenis antibiotik dalam tiga atau lebih kelas antibiotik (CDC, 2019). Kejadian MDR E. coli O157:H7 pada penelitian ini terjadi terhadap ampisilin, enrofloksasin, dan siprofloksasin, serta gentamisin. Keberadaan MDR E. coli dalam rantai makanan dapat menyebabkan masalah serius terhadap kesehatan manusia. Menurut CDC (2015) keberadaan mikroorganisme MDR dapat menyebabkan perpanjangan masa pengobatan, meningkatnya biaya pengobatan dan meningkatnya mortalitas.

Menurut penelitian Egbule et al. (2016) MDR E. coli 0157:H7 ditemukan pada sampel feses anakanak dengan diare yang dirawat di Rumah Sakit. Kejadian MDR E. coli O157 pada pasien diare dimanusia dapat dihubungkan dengan penggunaan air untuk konsumsi seperti air minum, rekreasi dan irigasi (Chigor et al., 2010).

Penemuan strain E. coli $0157: \mathrm{H} 7$ resistan antibiotik dan MDR pada penelitian ini cukup mengkhawatirkan, namun penelitian ini memiliki keterbatasan dalam identifikasi jenis faktor virulen dan identifikasi gen penyandi resistansi strain E. coli O157:H7 yang ditemukan. Pencegahan dan pengendalian STEC dapat dilakukan dengan implementasi prosedur manajemen keamanan pangan mulai dari peternakan (pre harvest), proses pemotongan (post harvest), retail, penanganan dan pengolahan sampai ke konsumen (Egbule et al., 2016). Sosialisasi tentang pentingnya higiene dan sanitasi mulai dari peternakan hingga penyajian juga perlu dilakukan sebagai tindakan pencegahan kejadian foodborne disease terutama akibat infeksi E. coli O157:H7.

Monitoring terhadap resistansi STEC juga penting dilakukan mengingat risiko penyebaran strain resistan dari makanan ke manusia dan transfer horizontal gen resistan dari STEC ke patogen lain (Mukherjee et al., 2017). Monitoring dan identifikasi strain STEC resistan perlu dilakukan secara berkala sebagai bahan informasi dalam usaha menetapkan langkah-langkah pengendalian resistansi antibiotik yang tepat.

Kesimpulan yang didapatkan dari penelitian ini adalah keberadaan isolat $\mathrm{E}$. coli O157:H7 resistan antibiotik pada daging kebab yang dijual di sekitar Kampus IPB Dramaga Bogor cukup tinggi (6/19; $31.6 \%$ ) dengan tingkat resistansi tertinggi terjadi terhadap gentamisin $(3 / 6 ; 50 \%)$ dan terdapat satu isolat E. coli O157:H7 yang termasuk MDR. Identifikasi $E$. coli O157:H7 pada RTE terutama kebab dan sifat resistansinya terhadap antibiotik diperlukan dalam rangka menyusun strategi dalam pencegahan foodborne disease dan pengendalian penyebaran resistansi antibiotik. 


\section{UCAPAN TERIMA KASIH}

Terima kasih diucapkan kepada Kementerian Pertanian untuk pemberian beasiswa tugas belajar S2. Terimakasih juga diucapkan kepada Laboratorium Kesehatan Masyarakat Veteriner Fakultas Kedokteran Hewan IPB, BBalitvet, dan seluruh pihak yang secara langsung maupun tidak langsung turut membantu terlaksananya penelitian ini.

"Penulis menyatakan tidak ada konflik kepentingan dengan pihak-pihak yang terkait dalam penelitian ini".

\section{DAFTAR PUSTAKA}

Ameer MA, Wasey A, Salen P. 2020. Escherichia coli (E. coli 0157 H7). In: StatPearls. Stat Pearls Publishing. Treasure Island. https://www.ncbi.nlm.nih.gov/books/NBK507845 1. Download: Juni 1, 2020.

Abreham S, Teklu A, Cox E, Tessema TS. 2019. Escherichia coli O157:H7: distribution, molecular characterization, antimicrobial resistance patterns and source of contamination of sheep and goat carcasses at an export abattoir, Mojdo, Ethiopia. BMC Microbiology. 19(215):1-14.

Amezquita-Lopez BA, Quinones B, Soto-Beltrain M, Lee BG, Yambao JC, Lugo-Melchor OY, Chaidez C. 2016. Antimicrobial resistance profiles of Shiga toxin-producing Escherichia coli $\mathrm{O} 157$ and Non 0157 recovered from domestic farm animals in rural communities in Northwestern Mexico. Antimicrobial Resistance and Infection Control 5(1):1-6.

[BSN] Badan Standardisasi Nasional. 2008. Tentang Metode Pengujian Cemaran Mikroba dalam Daging, Telur dan Susu, serta Hasil Olahannya. SNI No. 2897:2008. Jakarta (ID): BSN.

Bakri Z, Hatta M, Nasrum M. 2010. Deteksi keberadaan bakteri Escherichia coli O157:H7 pada feses penderita diare dengan metode kultur dan PCR. JST Kesehatan. 5(20):184-192

Bedasa S, Shiferaw D, Abraha A, Moges T. 2018. Occurrence and antimicrobial susceptibility profile of Echerichia coli $\mathrm{O} 157: \mathrm{H} 7$ from food of animal origin in Bishoftu town, Central Ethiopia. International Journal Food Contamination. 5(2):1-8.

Bekele T, Zewde G, Tefera G, Feleke A, Zerom K. 2014. Escherichia coli $\mathrm{O} 157: \mathrm{H} 7$ in Raw Meat in Addis
Ababa Ethiopia: Prevalence at an Abattoir and Retailers and Antimicrobial Susceptibility. International Journal Food Contamination. 1(4):1-8.

Beneduce L, Spano G, Massa S. 2003. Escherichia coli $\mathrm{O} 157: \mathrm{H} 7$ general characteristics, isolation and identifification techniques. Annals Microbiology. 53(4):511-527.

Bonilauri P, Leonelli R, Ferrarini G, Carobbi D, Ossiprandi MC, Dottori M, Cuccurese A. 2018. Kebab: can the traditional cooking process sanitize a natural contamination by Listeria monocytogenes? Italian Journal Food Safety. 7(7167):121-125.

Cagri-Mehmetoglu A. 2018. Food safety challenges associated with traditional foods of Turkey. Food Science Technology. 38(1):1-12.

[CLSI] Clinical and Laboratory Standards Institute. 2018. M100- Performance Standards for Antimicrobial Susceptibility Testing. $28^{\text {th }}$ ed. CLSI. West Valley.

[CLSI] Clinical and Laboratory Standards Institute. 2014. M100-S24 Performance Standards for Antimicrobial Susceptibility Testing. $24^{\text {th }}$ ed. CLSI. West Valley.

[CDC] Centers for Disease Control and Prevention. 2014. E. coli (Escherichia coli)https://www.cdc. gov/ecoli/general/index.html. Download: April 4, 2019

[CDC] Centers for Disease Control and Prevention. 2015. Multidrug Resistant Organism (MDRO) Management. https://www.cdc.gov/infection control/guidelines/mdro/background.html. Download: April 4, 2019.

[CDC] Centers for Disease Control and Prevention. 2019. Glossary of Terms. https://www.cdc.gov/ narms/resources/glossary.html. Download: Mei 14, 2019.

Chapman P, Cerda'n Malo A, Ellin M, Ashton R, Harkin M. 2001. Escherichia coli $\mathrm{O} 157$ in cattle and sheep at slaughter, on beef and lamb carcasses and in raw beef and lamb products in South Yorkshiire. International Journal Food Microbiology. 64:139-150.

Chigor VN, Umoh VJ, Smith SI, Igbinosa E, Okoh A. 2010. Multidrug resistance and plasmid patterns of Escherichia coli $\mathrm{O} 157$ and other E. coli isolated from diarrhoeal stools and surface waters from some selected sources in Zaria, Nigeria. International Journal Environmental Research and Public Health. 7(10):3831-3841. 
Constable PD, Hinchcliff KW, Done SH, Grünberg W. 2017. Veterinary Medicine. $11^{\text {th }}$ ed. Elsevier. Missouri. p436-621.

Darmawan Y, Swacita IBN, Suardana IW. 2015. Perbandingan bakteri Coliform, E. coli, E. coli O157, dan E. coli O157:H7 pada Sapi Bali di Mengwi, Badung, Bali. Indonesia Medicus Veterinus. 4(4):362-373.

Economou V, Gousia P. 2015. Agriculture and food animals as a source of antimicrobial resistant bacteria. Infection and Drug Resistance. 8:49-61.

Egbule OS, Owhe-Ureghe UB, Odih EE. 2016. Occurence of multidrug resistance among $E$. coli O157:H7 isolated from stool samples obtained from hospitalized children. Journal Probiotics and Health. 4(3): 1-4.

Greenwood D. 2010. Chapter 13- $\beta$ lactam Antibiotics: Cephalosporins. In: Antibiotics and Chemotheraphy. $9^{\text {th }}$ ed. Finch R, Greenwood D, Norrby S, Whitley R. editor. Elsevier. London. p170-199.

Kiranmayi CB, Krishnaiah N, Mallika EN. 2010. Escherichia coli $0157: \mathrm{H}_{7}$ - an emerging pathogen in foods of animal origin. 2010. Veterinary World. 3(8):382-289.

Kwiri R, Winini C, Tongonya J, Gwala W, Mpofu E, Mujuru F, Gwala ST, Makarichi L, Muredz P. 2014. Microbiological safety of cooked vended foods in an urban informal market: A case study of Mbare Msika, Harare, Zimbabwe. International Journal of Nutrition and Food Science. 3(3):216-221.

Liu Y, Liu JH. 2018. Monitoring colistin resistance in food animals, an urgent threat. Expert Review of Anti-infective Therapy. 16(6):443-446.

Malathi V, Revathi K, Devaraj SN. 2014. Antimicrobial resistance an interface between animal and human diseases. Indian Journal Veterinary and Animal Science Research. 43(2): 113-114.

Mukherjee S, Mosci RE, Anderson CM, Snyder BA, Collins J, Rudrik JT, Manning SD. 2017. Antimicrobial drug-resistant shiga toksin-producing Escherichia coli infections, Michigan, USA. Emerging Infectious Diseases. 23(9): 1609-1611.

O'Neill J. 2014. Review on Antimicrobial Resistance Antimicrobial Resistance: Tackling a Crisis for the Health and Wealth of Nations. London (UK): HM Government. p1-20.

Osaili TM, Al-Nabulsi A, Shaker RR, Jaradat JW, Taha M, Al-Kherasha M, Meherat M, Holley R. 2014.
Prevalence of Salmonella serovars, Listeria monocytogenes, and Escherichia coli $\mathrm{O} 157: \mathrm{H} 7$ in Mediterranian ready-to-eat meat products in Jordan. Journal Food Protection. 77(1):106-111.

Percival SL, Williams DW. 2014. Eschericia coli. In: Percival SL, Yates MV, Williams DW, Chalmers RM, Gray NF, editor. Microbiology of Waterborne Disease. Elsevier. San Diego. p89-117.

Quinn PJ, Markey BK, Leonard FC, FitzPatric ES, Fanning S, Hartigan PJ. Veterinary Microbiology and Microbial Disease. $2^{\text {nd }}$ ed. Blackwell. lowa.

Rachmawati F, Ariyanti T. 2017. Contamination of Escherichia coli $0157: \mathrm{H} 7$ in dairy cow farms. JITV. 22(4). 205-211.

Rivas M, Miliwebsky E, D'Astek B, Pianciola L. 2019. Escherichia. In: Liu D, editor. Handbook of Foodborne Diseases. CRC Press. Boca Raton. p318-327.

Rinca KF.Nindhia TS, Suardana IW. 2016. Faktorfaktor risiko penyebaran Escherichia coli O157:H7 pada Sapi Bali di Kuta Selatan, Badung, Bali. Jurnal Veteriner. 17(3): 374-382.

Schroeder CM, Meng J, DebRoy SC, Torcolini J, Zhao C, McDermott PF, Wagner DD, Walker RD, White DG. 2002. Antimicrobial resistance of Escherichia coli O26, O103, O111, O128, and 0145 from animals and humans. Emerging Infectious Diseases. 8(12):1409-1414.

Suardana IW, Ratnawati B, Sumiarto, Lukman DW, 2008. Deteksi keterkaitan keberadaan coliform, E. coli, dengan keberadaan agen zoonosis $E$. coli O157 dan E. coli O157:H7 pada feses manusia di Kabupaten Badung Provinsi Bali. Medicina. 39(3): 216-218.

Suardana IW, Utama HI, Wibowo MH. 2014. Identifikasi Escherichia coli O157:H7 dari feses ayam dan uji profil hemolisisnya pada media agar darah. Jurnal Kedokteran Hewan. 8(1): 1-5.

Ulukanli Z,Cavli P,TuzcuM.2006. Detection of Escherichia coliO157:H7 from beef Doner. G.U. Journal of Science. 19(2):99-104.

[WHO] World Health Organization. 2018. E. coli. https://www.who.int/news-room/factsheets/detail/e-coli. Download: Mei 142019.

Wibawa A. 2008. Faktor penentu kontaminasi bakteriologik pada makanan jajanan di Sekolah Dasar. Jurnal Kesehatan Masyarakat Nasional. $3(1): 1-8$. 